\title{
Metabolic balances of copper in patients with hepatolenticular degeneration submitted to vegetarian and mixed diets
}

\author{
HORACIO M. CANELAS ${ }^{1}$, FRANCISCO BASTOS DE JORGE, AND \\ WALDIR A. TOGNOLA \\ From the Departments of Neurology and Medicine, University of São Paulo School of Medicine, \\ São Paulo, SP, Brazil
}

Besides the use of chelating agents, aiming to produce a rise in cupruresis, a decrease of the positive copper balance in hepatolenticular degeneration has been attempted by means of lowering copper absorption. To this end cation exchange resins and potassium sulphide have been used. Nevertheless, the effectiveness of these drugs is still discussed, some investigators being sceptical (Denny-Brown, 1964; Scheinberg and Sternlieb, 1965), while others (Goldstein, Randall, Gross, and McGuckin, 1965) found an increase in the copper content in faeces promoted by the use of potassium sulphide and mainly of cation-exchange resins, and also that the penicillamine-induced negative copper balance was reinforced by the addition of carbacrylamine resins.

Another suggested method of treatment is the use of low copper diets containing 1.0 to $1.5 \mathrm{mg}$. of copper daily. However, this diet, as well as excluding several largely consumed foods, is very monotonous and has a low nutritional value. Moreover, as Scheinberg and Sternlieb (1965) stated, the net average quantity of copper which must be retained from a daily intake of several milligrams to account for the amounts of copper seen in organs of young adult patients with hepatolenticular degeneration is only about $50 \mu \mathrm{g}$., as absorption of copper is apparently greater in this disease than in control subjects. On the other hand, the comparative study of high and low copper diets in guinea-pigs (Holbrook, 1961) showed that the copper concentrations change in the blood and liver but not in the central nervous system: cupraemic increases up to $60 \mu \mathrm{g} . / 100 \mathrm{ml}$. did not raise the copper levels in the nervous tissue.

Good clinical results were obtained with high protein diets (Herz and Meyers, 1962; Smith, 1965), sometimes associated with restriction of lipids

1Present address: Clínica Neurologica, Caixa Postal 3461, São Paulo. SP, Brazil.
(Homburger, 1946). Iber, Chalmers, and Uzman (1957) found that alternating high and low protein diets increased both the copper and amino-acid urinary output.

Although in the literature reference is generally made only to high protein diets, Dimitz and Vujic in 1925 (cited by Wilson, 1954) had already mentioned the good results afforded by the use of a meatless diet. Later Schaltenbrand (1957) also reported transient improvement due to the prescription of a raw vegetable diet. Studying the copper metabolism of normal subjects, De Jorge (1965) found that vegetarian diets tend to make the metabolic balances negative.

These results led us to study the influence of a vegetarian diet on the copper balance of two cases of hepatolenticular degeneration.

\section{MATERIAL AND METHODS}

CASE 1 V.E. was a 22-year-old woman whose symptoms had started a year earlier; the neurological examination showed the characteristic facies, bilateral KayserFleischer corneal rings, a severe wing-beating tremor in the upper limbs, unsteady gait, slurred speech, and mild rigidity of the upper limbs. The mean blood serum copper content was $29 \mu \mathrm{g} . / 100 \mathrm{ml}$., caeruloplasmin level $3 \mathrm{mg}$./ $100 \mathrm{ml}$. (Houchin method), aminoaciduria $437 \mathrm{mg} / 24 \mathrm{hr}$. The liver biopsy showed a postnecrotic cirrhosis.

CASE 2 J.C.M. was a 27-year-old man whose disease started two years before with mental disorder and a severe tremor in the upper limbs. There were bilateral KayserFleischer rings but muscle tone, gait, and speech were normal. The mean serum copper content was $45 \mu \mathrm{g} . /$ $100 \mathrm{ml}$., caeruloplasmin $0 \mathrm{mg} . / 100 \mathrm{ml}$., aminoaciduria $410 \mathrm{mg} . / 24 \mathrm{hr}$. The liver biopsy showed fatty infiltration.

The vegetarian diet was balanced for amino acids and contained $421 \mathrm{~g}$. of carbohydrates, $69 \mathrm{~g}$. of proteins and $104 \mathrm{~g}$. of lipids, amounting to 3,053 calories. It contained $2,843 \mu \mathrm{g}$. of copper each day, while the mixed diet had 371 
$3,319 \mu \mathrm{g}$. The vegetarian diet was composed of coffee (400 g.), sugar (30 g.), salted bread (100 g.), butter (20 g.), apple (200 g.), beans (200 g.), maize flour (100 g.), rice (60 g.), lettuce (50 g.), banana (100 g.), oil (80 g.), and lemon $(20 \mathrm{~g}$.).

Case 1 was kept in metabolic balance for the 45 days, including 20 days on vegetarian diet, 13 days on mixed diet, and 12 days on vegetable diet again plus $2,000 \mathrm{mg}$. of D-penicillamine. Case 2 was kept in metabolic balance for 37 days, including 12 days on the vegetarian diet, 13 days on the mixed diet, and 12 days on the vegetarian diet plus $2,000 \mathrm{mg}$. of D-penicillamine. Each balance was divided into periods of from three to six days.

At the end of each period faeces and alimentary residues, which were collected in glass containers kept in a refrigerator, were weighed and homogenized. Duplicate samples of each material were then submitted to the analytical method. The ingesta were the difference between the known copper content of each type of diet and the concentration in the alimentary residues. Urine was collected daily under the same conditions as faeces, and the 24-hour volume determined.

All reagents were of the analytical grade and tested for copper contamination. The water used in all operations was redistilled in an all-glass distiller. The glassware used for analytical determinations was soaked overnight in chromic acid and then washed thoroughly with redistilled water and then boiled in a $20 \%$ hydrochloric acid solution for two hours, washed with enough redistilled water and put in an oven to dry within a glass container.

The tissues were dried in an oven at $100^{\circ} \mathrm{C}$. for several hours and were incinerated in a furnace working at $550^{\circ} \mathrm{C}$. overnight. The ashes were dissolved in a known volume of $2 \mathrm{~N}$ hydrochloric acid solution.

Copper was determined by the diethyldithiocarbamate method (De Jorge, Canelas, and Costa-Silva, 1962), and the estimations were made in duplicate.

\section{RESULTS}

The results are summarized in Tables I and II.

\section{COMMENT}

The use of a vegetarian diet promoted a remarkable decrease in the positive copper balance in both patients. In case 1 the average daily copper balance on mixed diet was $+413 \mu \mathrm{g}$. and fell to $+126 \mu \mathrm{g}$. with the vegetable diet. In case 2 the balance fell from $+495 \mu \mathrm{g}$. to $+83 \mu \mathrm{g}$.

No change was evidenced in the blood serum copper. A tendency to an increase in the copper content of faeces was observed. The urinary output did not show a significant change in case 2 , while in case 1, after a great fall from the first to the second period, the cupruresis did not change until the last period, when it rose again.

When D-penicillamine was associated with the vegetarian diet, the usual intense rise in cupruresis was noted, and consequently the copper balance became strongly negative. The blood copper increase was not accompanied by the caeruloplasmin content, indicating that it was due to a rise in the direct reacting copper.

It is difficult to explain the results obtained with the use of vegetarian diets in hepatolenticular degeneration as regards copper metabolic balance. Taking into account the increase of the copper concentration in faeces promoted by this diet, the view may be advanced that the absorption of copper is decreased, probably by binding on to some unabsorbed component of the diet.

TABLE I

\begin{tabular}{|c|c|c|c|c|c|c|c|c|}
\hline \multirow{3}{*}{ Diet } & \multirow{3}{*}{ Periods (1964) } & \multicolumn{7}{|c|}{ METABOLIC BALANCE OF COPPER IN CASE 1 (V.E.) } \\
\hline & & \multirow[t]{2}{*}{ Days } & \multirow{2}{*}{$\begin{array}{l}\text { Ingesta } \\
(\mu g . / \text { day })\end{array}$} & \multicolumn{2}{|c|}{ Excreta ( $\mu g . /$ day) } & \multirow{2}{*}{$\begin{array}{l}\text { Balance } \\
\text { ( } \mu \mathrm{g} . / \text { day })\end{array}$} & \multicolumn{2}{|l|}{ Blood Serum } \\
\hline & & & & Urine & Faeces & & $\begin{array}{l}\text { Copper } \\
(\mu \mathrm{g} . / 100 \mathrm{ml} .)\end{array}$ & $\begin{array}{l}\text { Caeruloplasmin } \\
\text { (mg./100 ml.) }\end{array}$ \\
\hline Vegetable & $\begin{array}{l}27 \text { Jan.-29 Jan. } \\
30 \text { Jan.- } 2 \text { Feb. } \\
3 \text { Feb.- } 5 \text { Feb. } \\
6 \text { Feb.- } 9 \text { Feb. } \\
10 \text { Feb.-15 Feb. } \\
\text { Total }\end{array}$ & $\begin{array}{c}3 \\
4 \\
3 \\
4 \\
6 \\
20\end{array}$ & $\begin{array}{l}2,244 \\
2,843 \\
2,843 \\
2,424 \\
2,666\end{array}$ & $\begin{array}{r}1,032 \\
382 \\
387 \\
307 \\
782\end{array}$ & $\begin{array}{l}1,336 \\
2,497 \\
2,098 \\
2,069 \\
1,588\end{array}$ & $\begin{array}{r}-124 \\
-36 \\
+358 \\
+48 \\
+296 \\
+126\end{array}$ & $\begin{array}{l}41 \\
36 \\
48 \\
41\end{array}$ & $\begin{array}{l}0 \\
0 \\
0 \\
0\end{array}$ \\
\hline Veetarian nlus & $\begin{array}{l}17 \text { Mar.-20 Mar. } \\
21 \text { Mar.-23 Mar. } \\
24 \text { Mar.-26 Mar. } \\
27 \text { Mar.-29 Mar. } \\
\text { Total }\end{array}$ & $\begin{array}{r}4 \\
3 \\
3 \\
3 \\
13\end{array}$ & $\begin{array}{l}3,076 \\
3,319 \\
3,246 \\
3,197\end{array}$ & $\begin{array}{l}1,230 \\
1,426 \\
1,133 \\
1,886\end{array}$ & $\begin{array}{r}1,744 \\
1,693 \\
780 \\
1,128\end{array}$ & $\begin{array}{r}+56 \\
+200 \\
+1,333 \\
+183 \\
+413\end{array}$ & $\begin{array}{l}30 \\
32 \\
41 \\
38\end{array}$ & $\begin{array}{l}\mathbf{0} \\
\mathbf{0} \\
\mathbf{0} \\
\mathbf{0}\end{array}$ \\
\hline $\begin{array}{l}\text { Vegetarian plus } \\
\text { D-penicillamine }\end{array}$ & $\begin{array}{l}19 \text { Apr.-21 Apr. } \\
22 \text { Apr.-24 Apr. }{ }^{1} \\
25 \text { Apr.-27 Apr. }{ }^{1} \\
28 \text { Apr.-30 Apr. }{ }^{1} \\
\text { Total }\end{array}$ & $\begin{array}{r}3 \\
3 \\
3 \\
3 \\
3 \\
12\end{array}$ & $\begin{array}{l}2,408 \\
2,726 \\
2,835 \\
2,379\end{array}$ & $\begin{array}{l}1,312 \\
2,741 \\
6,377 \\
8,744\end{array}$ & $\begin{array}{l}1,053 \\
1,980 \\
1,856 \\
1,782\end{array}$ & $\begin{array}{r}+43 \\
-1,995 \\
-5,398 \\
-8,147 \\
-3,847\end{array}$ & $\begin{array}{l}40 \\
55 \\
67 \\
68\end{array}$ & $\begin{array}{l}\mathbf{0} \\
\mathbf{0} \\
\mathbf{0} \\
\mathbf{0}\end{array}$ \\
\hline
\end{tabular}

${ }^{1} \mathrm{D}$-penicillamine, $500 \mathrm{mg}$. four times a day. 
TABLE II

METABOLIC BALANCE OF COPPER IN CASE 2 (J.C.M.)

\begin{tabular}{|c|c|c|c|c|c|c|c|c|}
\hline \multirow[t]{2}{*}{ Diet } & \multirow[t]{2}{*}{ Periods (1964) } & \multirow[t]{2}{*}{ Days } & \multirow{2}{*}{$\begin{array}{l}\text { Ingesta } \\
(\mu g . / \text { day })\end{array}$} & \multicolumn{2}{|c|}{ Excreta $(\mu g . /$ day $)$} & \multirow{2}{*}{$\begin{array}{l}\text { Balance } \\
(\mu g . / \text { day })\end{array}$} & \multicolumn{2}{|l|}{ Blood Serum } \\
\hline & & & & Urine & Faeces & & $\begin{array}{l}\text { Copper } \\
(\mu \mathrm{g} . / 100 \mathrm{ml} .)\end{array}$ & $\begin{array}{l}\text { Caeruloplasmin } \\
(\mathrm{mg} . / 100 \mathrm{ml} .)\end{array}$ \\
\hline Vegetarian & $\begin{array}{l}14 \text { Oct. }-16 \text { Oct. } \\
17 \text { Oct. }-19 \text { Oct. } \\
20 \text { Oct. }-22 \text { Oct. } \\
23 \text { Oct. }-25 \text { Oct. } \\
\text { Total }\end{array}$ & $\begin{array}{r}3 \\
3 \\
3 \\
3 \\
12\end{array}$ & $\begin{array}{l}2,540 \\
2,945 \\
2,836 \\
2,630\end{array}$ & $\begin{array}{r}1,105 \\
1,245 \\
1,015 \\
915\end{array}$ & $\begin{array}{l}1,145 \\
1,648 \\
1,756 \\
1,790\end{array}$ & $\begin{array}{r}+290 \\
+52 \\
+65 \\
-75 \\
+83\end{array}$ & $\begin{array}{l}\overline{28} \\
40 \\
35\end{array}$ & $\begin{array}{l}\overline{0} \\
0 \\
0\end{array}$ \\
\hline Mixed & $\begin{array}{l}19 \text { Aug.-21 Aug. } \\
22 \text { Aug.-25 Aug. } \\
26 \text { Aug.-28 Aug. } \\
29 \text { Aug.-31 Aug. } \\
\text { Total }\end{array}$ & $\begin{array}{r}3 \\
4 \\
3 \\
3 \\
13\end{array}$ & $\begin{array}{l}3,285 \\
3,285 \\
2,946 \\
3,285\end{array}$ & $\begin{array}{l}1,105 \\
1,208 \\
1,416 \\
1,273\end{array}$ & $\begin{array}{l}1,892 \\
1,414 \\
1,504 \\
1,064\end{array}$ & $\begin{array}{r}+288 \\
+663 \\
+26 \\
+948 \\
+495\end{array}$ & $\begin{array}{l}40 \\
42 \\
32\end{array}$ & $\begin{array}{c}0 \\
0 \\
0\end{array}$ \\
\hline \multicolumn{9}{|l|}{ Vegetarian plus } \\
\hline D-penicillamine & $\begin{array}{l}4 \text { Nov.- } 6 \text { Nov. } \\
7 \text { Nov.- } 9 \text { Nov. }{ }^{1} \\
10 \text { Nov. } 12 \text { Nov. } \\
13 \text { Nov.-15 Nov. } \\
\text { Total }\end{array}$ & $\begin{array}{r}3 \\
3 \\
3 \\
3 \\
12\end{array}$ & $\begin{array}{l}2,986 \\
2,742 \\
2,620 \\
2,585\end{array}$ & $\begin{array}{l}1,415 \\
2,208 \\
5,105 \\
6,626\end{array}$ & $\begin{array}{l}1,556 \\
1,618 \\
1,651 \\
1,018\end{array}$ & $\begin{array}{r}+15 \\
-84 \\
-3,136 \\
-5,059 \\
-2,066\end{array}$ & $\begin{array}{r}35 \\
60 \\
8 \\
58\end{array}$ & $\begin{array}{l}0 \\
0 \\
0 \\
0\end{array}$ \\
\hline
\end{tabular}

${ }^{1} \mathrm{D}$-penicillamine, $500 \mathrm{mg}$. four times a day.

\section{SUMMARY}

The copper metabolic balances of two patients with hepatolencitular degeneration submitted to vegetarian and mixed diets were studied. A marked decrease in the positive copper balance was induced by the use of a vegetarian diet. The finding of an increase in the copper concentration in faeces may support the view that copper would be strongly bound to some unabsorbed component of the diet.

\section{REFERENCES}

De Jorge, F. B. (1965). Alguns aspectos do metabolismo do cobre. (Monograph). Universidade de São Paulo, São Paulo.

-, Canelas, H. M., and Costa-Silva, A. (1962). Contribuição ao estudo do metabolismo do cobre. I: Metodologia da determinação do cobre em materiais biológicos. Rev. paul. Med., 61, 350-355.

Denny-Brown, D. (1964). Wilson's disease (hepato-lenticular degeneration): changing clinical concepts. Rev. Neuro-psiquiat., 27, 362-375.
Goldstein, N. P., Randall, R. V., Gross, J. B, and McGuckin, W. F. (1965). Copper balance studies in Wilson's disease: observations on the effect of penicillamine, carbacrylamine resins, and potassium sulfide. Arch. Neurol. (Chic.), 12, 456-462.

Herz, E., and Meyers, R. (1962). The extrapyramidal diseases. In Clinical Neurology, 2nd ed. vol. 3, pp. 1285-1337, edited by A. B. Baker. Hoeber-Harper, New York.

Holbrook, J. R. (1961). Effects of alterations in serum copper levels upon the liver, basal ganglia and cerebellar cortex in the guinea-pig. J. Neurochem., 7, 60-68.

Homburger, F. (1946). Hepatolencitular degeneration. II. Nutritional factors: observations on methionine and high-protein diets. New Eng. J. Med., 234, 683-687.

Iber, F. L., Chalmers, T. C., and Uzman, L. L. (1957). Studies of protein metabolism in hepatolenticular degeneration. Metabolism, 6, 388-396.

Schaltenbrand, G. (1957). Enfermedades del Sistema Nervioso. Translated from the first German edition by N. Lloret Barber and J. M. Masriera y Segalés, p. 247. Edit. Científico Médica, Barcelona.

Scheinberg, I. H., and Sternlieb, I. (1965). Wilson's disease. Ann. Rev. Med., 16, 119-134.

Smith, B. H. (1965). Principles of Clinical Neurology, p. 271. Year Book Medical Publishers, Chicago.

Wilson, S. A. K., (1954). Neurology, 2nd ed. Vol. 2, p. 967. Butterworth, London. 